\title{
Winding machine additional overload state indication as supporting solution for mine shaft hoist operators
}

\begin{abstract}
Dangerous events that take place in the mining plant always give us a chance to rethink whether the design of a faulty device could have been improved enough to prevent such a situation. The same scenario takes place with mining shaft hoist. Without a doubt, a starting point for discussions about additional mining shaft hoist security measures is the last dangerous situation that took place in a Silesian mine in 2017. This article is an analysis of the probable causes and conclusions that can be drawn from that incident.
\end{abstract}

Key words: mining shaft hoist, logger, winding machine control system

\section{MINING SHAFT HOIST}

\section{GENERAL CHARACTERISTICS}

The mining fall in which the incident took place is a 7.5-m-radius double-compartment shaft with a depth of $710.5 \mathrm{~m}$. In Compartment $\mathrm{A}$, the mining level is at $-650 \mathrm{~m}$, whereas Compartment B's mining level is $-500 \mathrm{~m}$. The arrangement of the individual vessels in the shaft shield is shown in Figure 1.

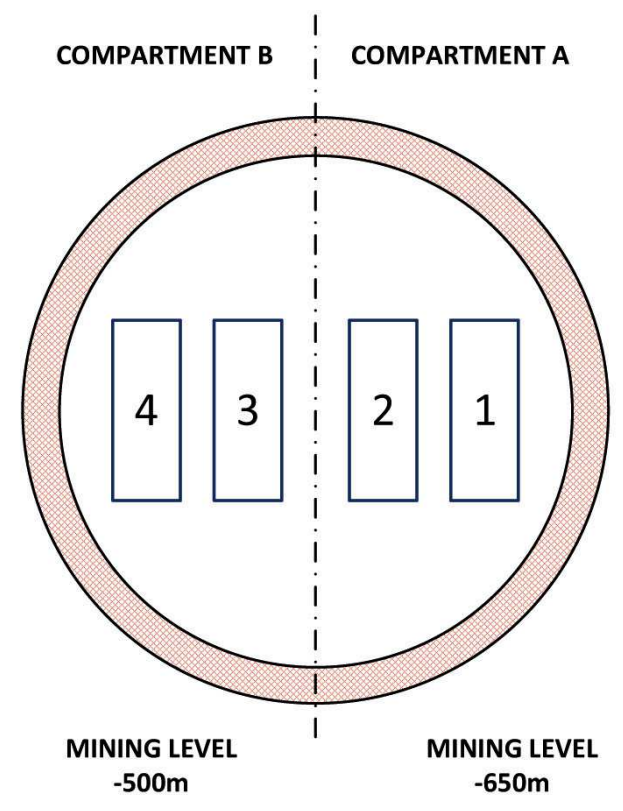

Fig. 1. Shaft disc vessel arrangement
The incident took place in Compartment A equipped with a Koepe wheel-type 4L5500/2×3600 winding machine [1] approved in accordance with [2]. The Koepe pulley is $5.5 \mathrm{~m}$ in diameter and supplied with two PW motors (3.6 MW each) working on a common shaft. The motors are powered by a static thyristor converter. The motor excitation systems are powered by bidirectional converters. The direction of the rotation is changed by changing the direction of the current flow through the excitation circuits. The mine shaft hoist is equipped with disc brakes. Four pairs of spring-hydraulic actuators are mounted on each of the four brake stands.

The control system of the winding machine enables mining in manual or automatic modes. The AR-3c recorder was used to record the operating parameters of the hoist.

The hoisting machine is a two-vessel machine with a total coal transport mass of $30 \mathrm{Mg}$ and a vessel linear velocity of $16 \mathrm{~m} / \mathrm{s}$ in the shaft. The locations of the individual levels are shown in Figure 2.

The shaft is equipped with a rigid vessel mounting. The shaft-guiding lines with dimensions of $160 \times 220 \times 9000 \mathrm{~mm}$ are fixed to $150 \times 200$ girders placed on the shaft lining $4.5 \mathrm{~m}$ apart.

To guide the vessels in the guidelines, sets of rolling guides are used that are mounted on the head and lower arm of each vessel. 


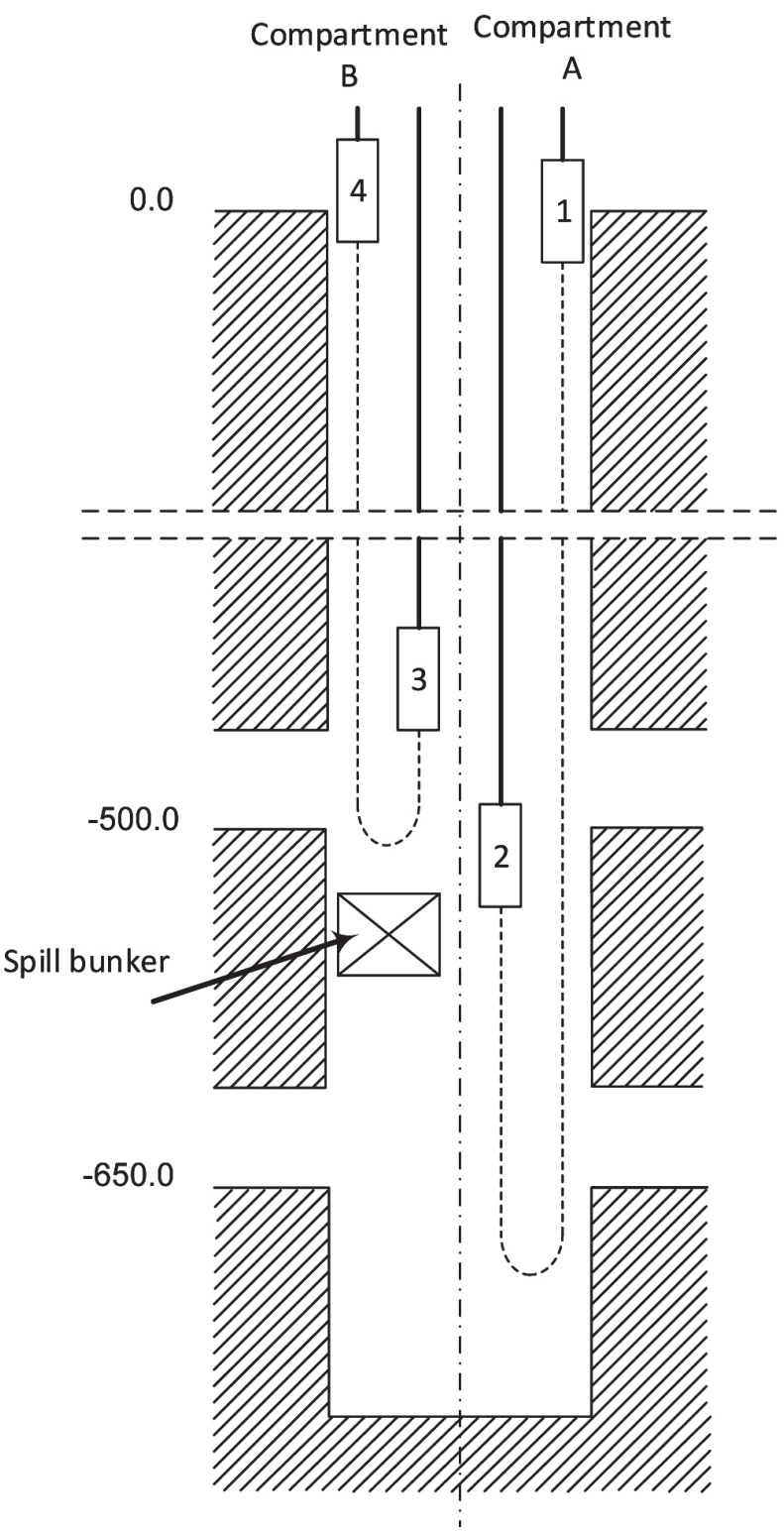

Fig. 2. Cross-section of shaft with location of levels

\section{EVENT DESCRIPTION}

The unfortunate event took place during working hours in Compartments A and B. As a result of a coal overload, Skip No. 2 hit Compartments B's spill bunker's steel parts that were sticking out beyond the safe zone. While descending, Skip No. 2 was suddenly stopped by the protruding elements of the tank and then suddenly released. The cause was probably the displacement of these parts. Description and reasons of this accident are described in [3]. As a result, the following components were damaged:

- shaft guiding rails,

- shaft buntons installed on the south side,

- wiremash partings,

- balance rope turning station,

- skip,

- skip load suspension,

- 4 head ropes,

- steel-rubber tailrope rubber coating.

The following question arises: were there no symptoms before then that could have indicated that something disturbing was happening in the mining shaft?

For this purpose, records from the logger installed in accordance with [2] were used. The results of the analysis are presented in a later part of this article.

\section{AR-3c LOGGER DATA}

An AR-3c logger is built in Compartment A. It is setup to $\log$ all control and diagnostic signals required to analyze any incorrect behavior of the mining shaft elements [4].

In a separately excited DC machine, the torque generated on the machine shaft is directly proportional to the current of the main circuit (armature circuit).

In the case of stopping Vessel No. 2 by the construction of the spill bunker, the load torque suddenly decreased.

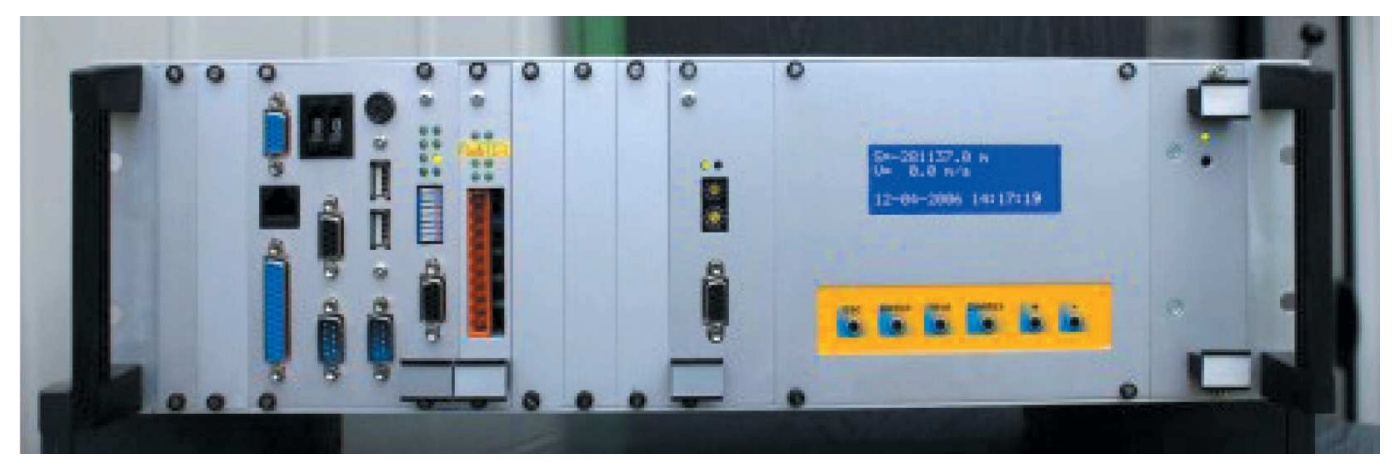

Fig. 3. AR-3c logger 


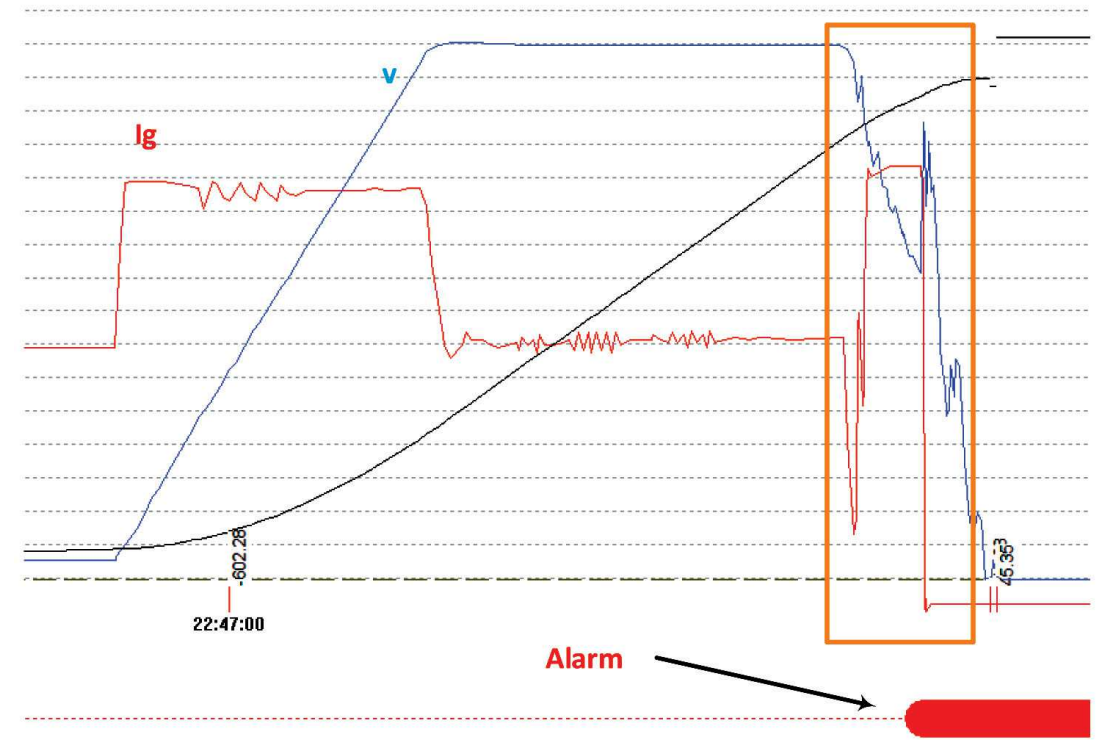

Fig. 4. Logger data during incident

a)

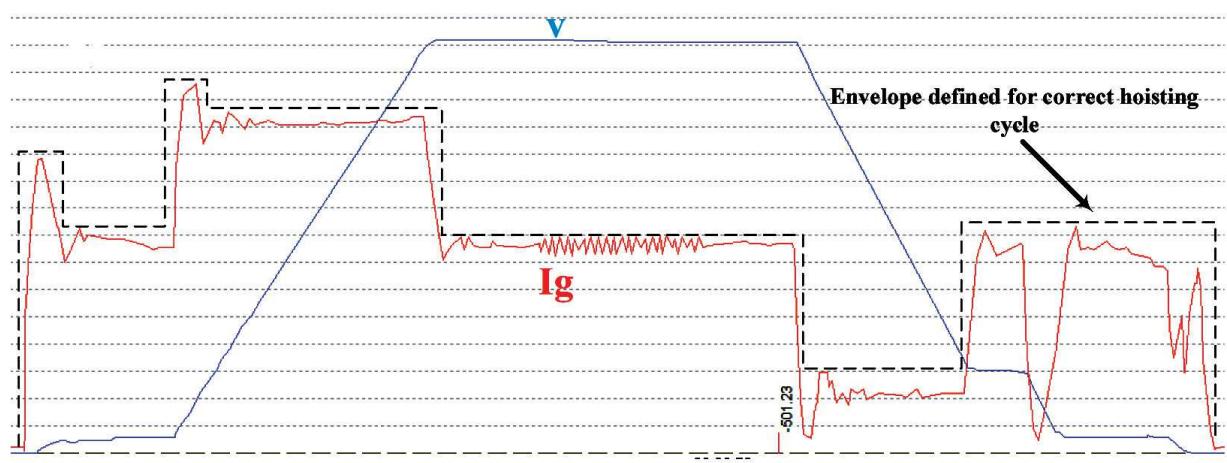

b)

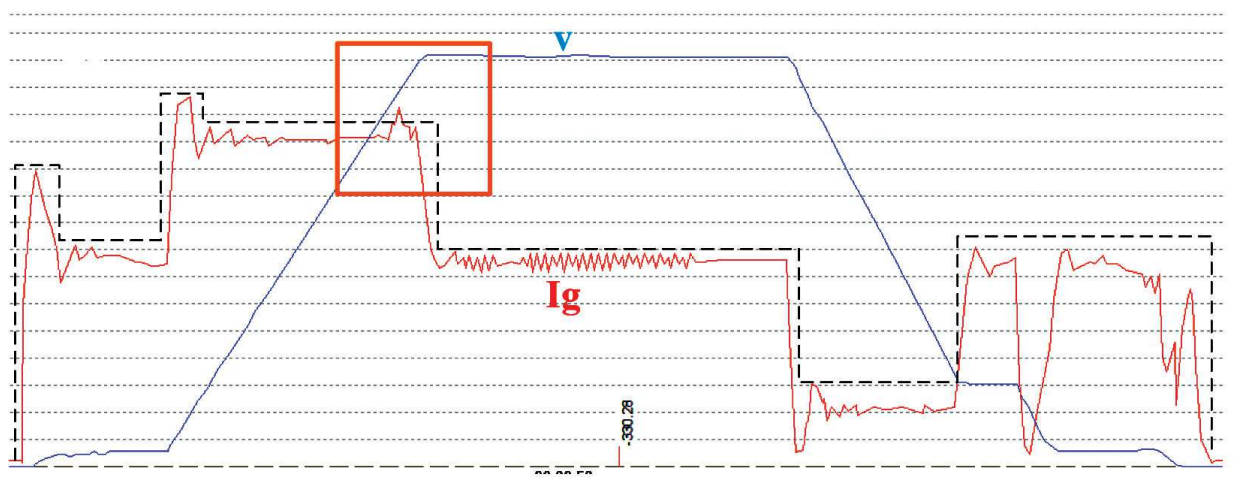

c)

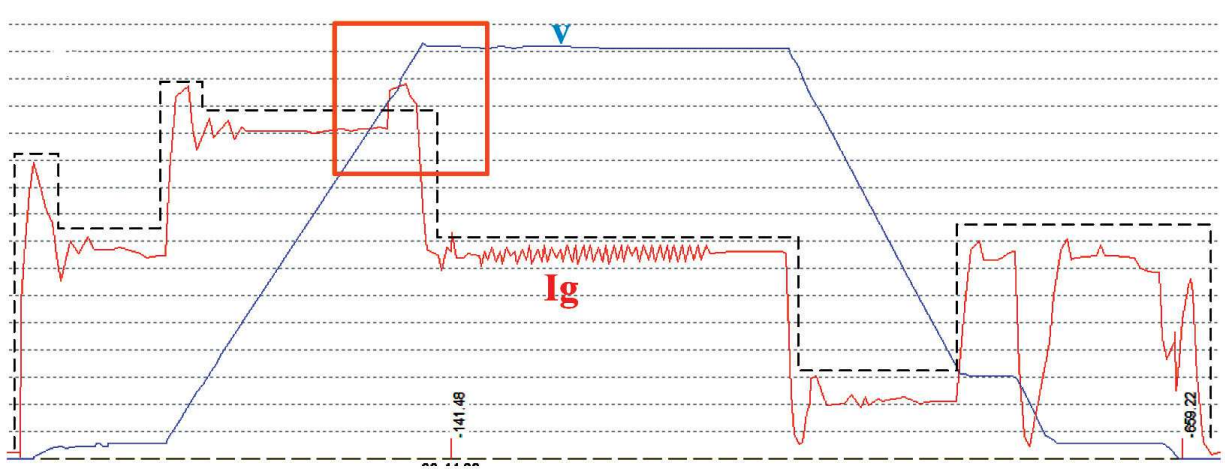

Fig. 5. Main circuit current Ig and vessel speed $v$ waveforms - data acquired from AR-3c logger: a) no disturbances visible (correct waveforms); b) three cycles before incident; $c$ ) cycle directly before incident 
The regulation system behaved properly. The current value dropped down to rise to its maximum value limited by regulator settings. At this point, the machine became a single-end machine. After this, the second vessel release skip went into a freefall. This caused its speed to rise above the permissible value and the machine to be switched off due to exceeding the maximum limit.

\section{DESCRIPTION OF CONDITIONS ON BASIS OF LOGGER DATA}

An analysis of the winding machine logger records was carried out in a wider range than solely at the time of the event.

The ten cycles preceding the incident were analyzed. Further than three cycles before the event, no disturbing changes in either the current or speed can be observed (Fig. 5a). For each form of the current waveforms in Figure 5, the envelope was applied on the basis of the normal course, which is information regarding whether there was an anomaly in the system. Three cycles before the occurrence of the event, an increase of approx. 500A in the main circuit current is visible above the value set for this fragment of the hoisting cycle. The full Vessel 2 was ascending during this time. It can be concluded that the vessel was already in contact with a deviated design of the adjacent compartment tank. The operation of the shaft station devices suggested that disturbing noises were heard in the mining shaft. In the cycle preceding the event, the increase in current when passing the vessel in the vicinity of the tank was already at $900 \mathrm{~A}$ and lasted much longer (Fig. 5c).

\section{CONCLUSIONS}

On the basis of the analysis of the winding machine logger data, it can be stated that it was possible to detect the symptoms of an impending threat earlier. For several cycles before the incident, it was possible to observe anomalies in the course of the main circuit current. The current changes were caused by a variable load torque resulting from the appearance of an additional obstacle to Vessel 2.

It is not possible to detect this type of anomaly only by observing the current waveforms on the driver's desk or in the logger. To properly respond to such irregularities, it would be necessary to place an addi- tional indicator of such a state on the driver's desk as well as appropriate changes in the regulations [5].

In the form of a visual signal (a glowing lamp) placed on the driver's desk, this indicator would be activated when the permissible value of the current is exceeded by the assumed value for a given fragment of the driving diagram. If established in double-compartment shafts with different levels of extraction, it would require the service staff to take control actions in case of its activation.

This would be an element that should draw the attention of the staff, especially the supervision workers. If there is an overload of the machine in the form of an increase in current, this is due to the operation of an additional load moment, which can have various causes. For the people controlling the technical condition of shaft reinforcement and the auxiliary equipment of the shaft, it is necessary to assess whether vessels on their ways encounter obstacles that may cause dangerous consequences. The implementation of this type of indication device is easy from the technical point of view, as a current measurement is already carried out in each machine.

\section{References}

[1] Szklarski L., Zarudzki J.: Elektryczne maszyny wyciagowe, PWN, Warszawa 1998.

[2] The Regulation of the Council of Ministers of 30 April 2004 on the approving of products for use in mining plants, Journal of Laws 2004, No. 99, item 1003.

[3] Kiercz M., Rokita T.: Awaria górniczego wyciąu szybowego szybu dwuprzedziałowego, "Bezpieczeństwo Pracy i Ochrona Środowiska w Górnictwie" 2018, 11: 8-13.

[4] Digital logger AR-3c. User manual. MicroSTER, Katowice, May 2005.

[5] Regulation of the Minister of Energy of November 23, 2016, on detailed requirements for the operation of underground mining facilities, Journal of Laws 2017, item 1118.

TOMASZ SIOSTRZONEK, Ph.D., Eng. JAKUB WÓJCIK, M.Sc., Eng. Department of Power Electronics and Energy Control Systems Faculty of Electrical Engineering, Automatics, Computer Science, and Biomedical Engineering AGH University of Science and Technology al. A. Mickiewicza 30, 30-059 Krakow, Poland \{tsios,jakubwojcik\}@agh.edu.pl

Piotr TRÓJCA, M.Sc., Eng. State Mining Authority Specialized Mining Office ul. Obroki 87, 40-833 Katowice, Poland sug@wug.gov.pl 


\title{
Dodatkowa sygnalizacja stanów przeciążenia silnika maszyny wyciągowej jako czynnik wspomagający pracę osób obsługujących górniczy wyciąg szybowy
}

\begin{abstract}
Występowanie niebezpiecznych zdarzeń w ruchu zakładu górniczego powinno skłonić do przemyśleń, czy konstrukcja danego urządzenia nie może zostać poprawiona w taki sposób, aby zapobiegać tego typu zdarzeniom. Doktadnie tak samo dzieje się w przypadku górniczego wyciagu szybowego. Ostatnie niebezpieczne zdarzenie, które miato miejsce w 2017 roku w jednej ze śląskich kopalń, stanowi punkt wyjścia w dyskusji nad dodatkowymi zabezpieczeniami górniczego wyciagu szybowego. W artykule przedstawione sa informacje na temat potencjalnych przyczyn wystapienia tego stanu $i$ wnioski, jakie nasuwaja się po analizie materiatu dotyczacego tej sytuacji.
\end{abstract}

Słowa kluczowe: górniczy wyciag szybowy, rejestrator, układ sterowania maszyny wyciagowej

\section{OGÓLNA CHARAKTERYSTYKA GÓRNICZEGO WYCIĄGU SZYBOWEGO}

Zdarzenie nastąpiło w szybie dwuprzedziałowym o średnicy 7,5 m i głębokości 710,5 m. W przedziale oznaczonym literą A wydobycie prowadzone jest z poziomu $-650 \mathrm{~m}$, a w przedziale $\mathrm{B}-\mathrm{z}$ poziomu $-500 \mathrm{~m}$. Rozmieszczenie w tarczy szybu poszczególnych naczyń pokazano na rysunku 1.

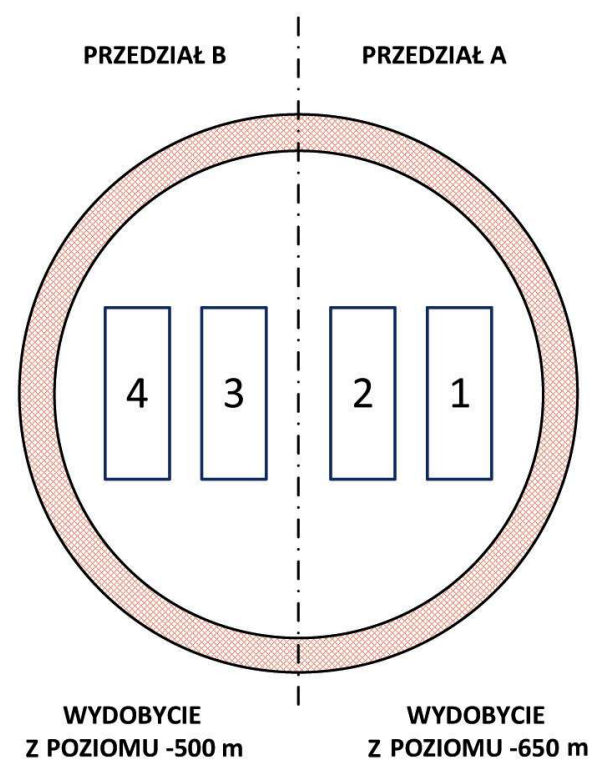

Rys. 1. Tarcza szybu z rozmieszczeniem naczyń
Zdarzenie dotyczy przedziału A. Maszyna wyciągowa typu 4L5500/2×3600 zainstalowana w tym przedziale to napęd z kołem typu Koepe [1], dopuszczona zgodnie z [2]. Średnica linopędni wynosiła 5,5 $\mathrm{m}$ i jest napędzana dwoma silnikami typu PW (o mocy 3,6 MW każdy) pracującymi na wspólnym wale, napędzając jedno koło pędne. Silniki zasilane są przez tyrystorowe, statyczne, nienawrotne przekształtniki mostkowe, a układy wzbudzeń silników - przez przekształtniki dwukierunkowe. Zmiana kierunku obrotów odbywa się przez zmianę kierunku przepływu prądu przez obwody wzbudzeń.

Górniczy wyciąg szybowy wyposażony jest w hamulce tarczowe. Na każdym z czterech stojaków hamulcowych zostały zamocowane cztery pary siłowników sprężynowo-hydraulicznych.

Układ sterowania maszyny wyciągowej umożliwia prowadzenie wydobycia w trybie ręcznym i automatycznym. Do rejestracji parametrów pracy wyciągu zastosowano rejestrator AR-3c.

Wyciąg jest dwunaczyniowy o masie transportowanego urobku $30 \mathrm{Mg}$ i prędkości liniowej naczynia w szybie $16 \mathrm{~m} / \mathrm{s}$. Usytuowanie poszczególnych poziomów zostało przedstawione na rysunku 2.

Prowadzenie naczyń w szybie jest sztywne. Prowadniki mają wymiary $160 \times 220 \times 9000 \mathrm{~mm}$ i są przymocowane do dźwigarów o wymiarach $150 \times 200$ zamocowanych do obmurza w odstępach $4,5 \mathrm{~m}$. 
Do prowadzenia naczyń w ciągach prowadniczych wykorzystywane są zestawy prowadnic tocznych zamontowanych na głowicy i ramie dolnej każdego naczynia.

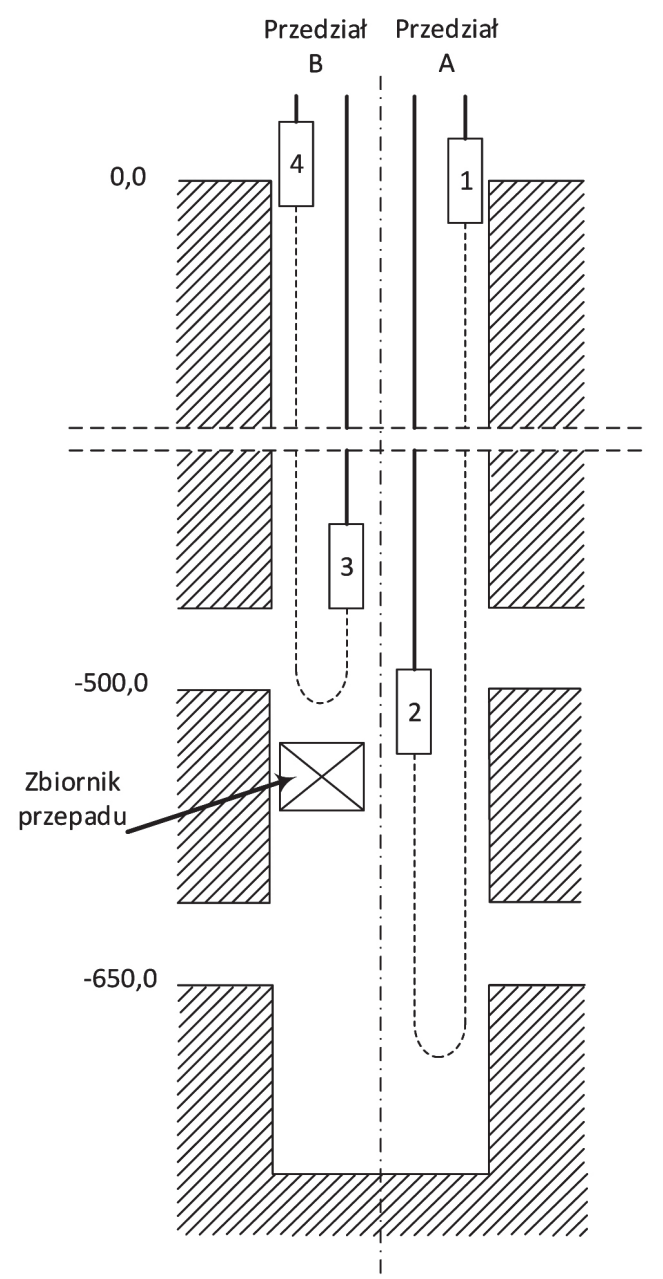

Rys. 2. Przekrój szybu z usytuowaniem poziomów

\section{OPIS ZDARZENIA}

Do niebezpiecznego zdarzenia doszło $\mathrm{w}$ trakcie prowadzenia wydobycia w przedziale A i B. Skip nr 2 uderzył w wystające poza dozwoloną granicę, stalowe elementy zbiornika przepadu przedziału B. Było to wynikiem zbyt dużego obciążenia konstrukcji zbiorni- ka wynikające z nagromadzenia urobku. Poruszający się w dół skip 2 został zatrzymany nagle przez wystające elementy zbiornika, a następnie uwolniony, prawdopodobnie na skutek przemieszczenia się tych elementów. Opis tego zdarzenia i potencjalne przyczyny zdarzenia zostały opisane w [3]. W wyniku tego zostały uszkodzone następujące elementy:

- prowadniki szybowe,

- dźwigary szybowe zabudowane po jednej stronie południowej,

- elementy przedziału drabinowego,

- stacja zwrotna lin wyrównawczych,

- skip,

- zawieszenie nośne skipu,

- cztery liny nośne,

- powłoki gumowe lin wyrównawczych stalowo-gumowych.

Powstaje pytanie, czy wcześniej nie było objawów, które mogłyby wskazywać na to, że coś niepokojącego dzieje się w szybie?

Do tego celu wykorzystano zapisy $\mathrm{z}$ aparatu rejestrującego zainstalowanego zgodnie z [2]. Wyniki analizy przedstawiono w dalszej części artykułu.

\section{ZAPISY Z REJESTRATORA AR-3c}

Rejestrator AR-3c zabudowany w górniczym wyciągu szybowym przedziału A rejestruje sygnały, które pozwalają na kontrolowanie i diagnozowanie nieprawidłowego zachowania się elementów górniczego wyciągu szybowego [4].

W maszynie z obcowzbudnym silnikiem prądu stałego moment obciążenia napędu wytwarzany na wale maszyny jest wprost proporcjonalny do wartości natężenia prądu obwodu głównego (obwodu twornika).

$\mathrm{W}$ przypadku zatrzymania naczynia nr 2 przez konstrukcję zbiornika przepadu nagle został zmniejszony moment obciążenia.

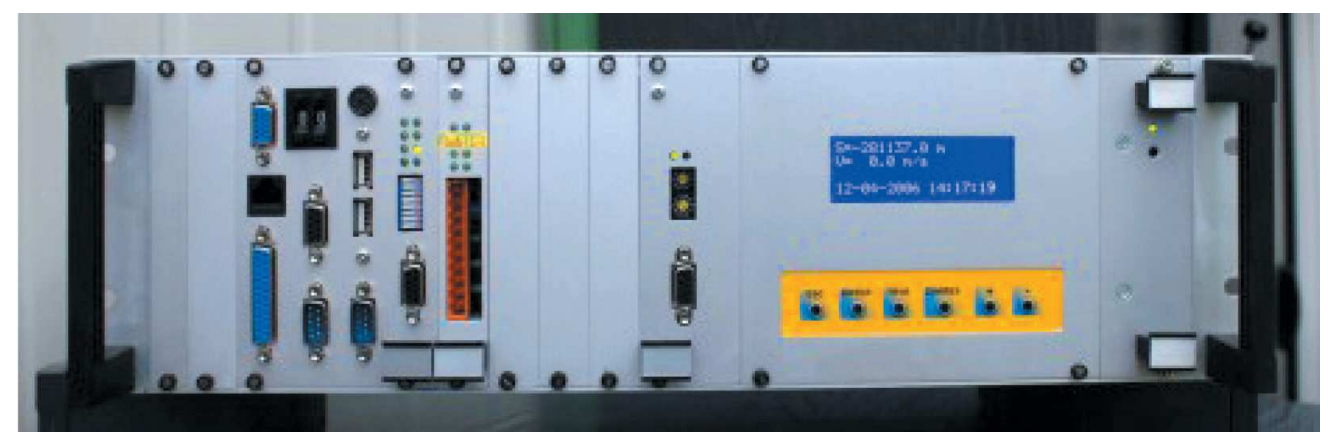

Rys. 3. Rejestrator $A R-3 c$ 


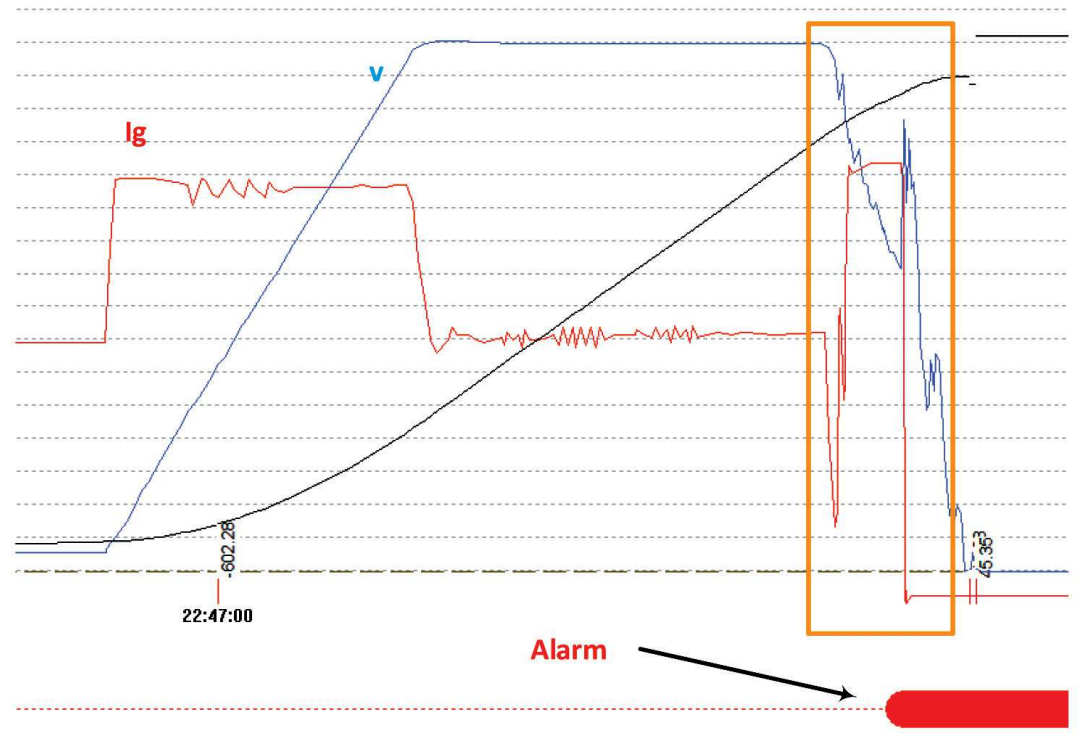

Rys. 4. Zapis z rejestratora - moment zdarzenia
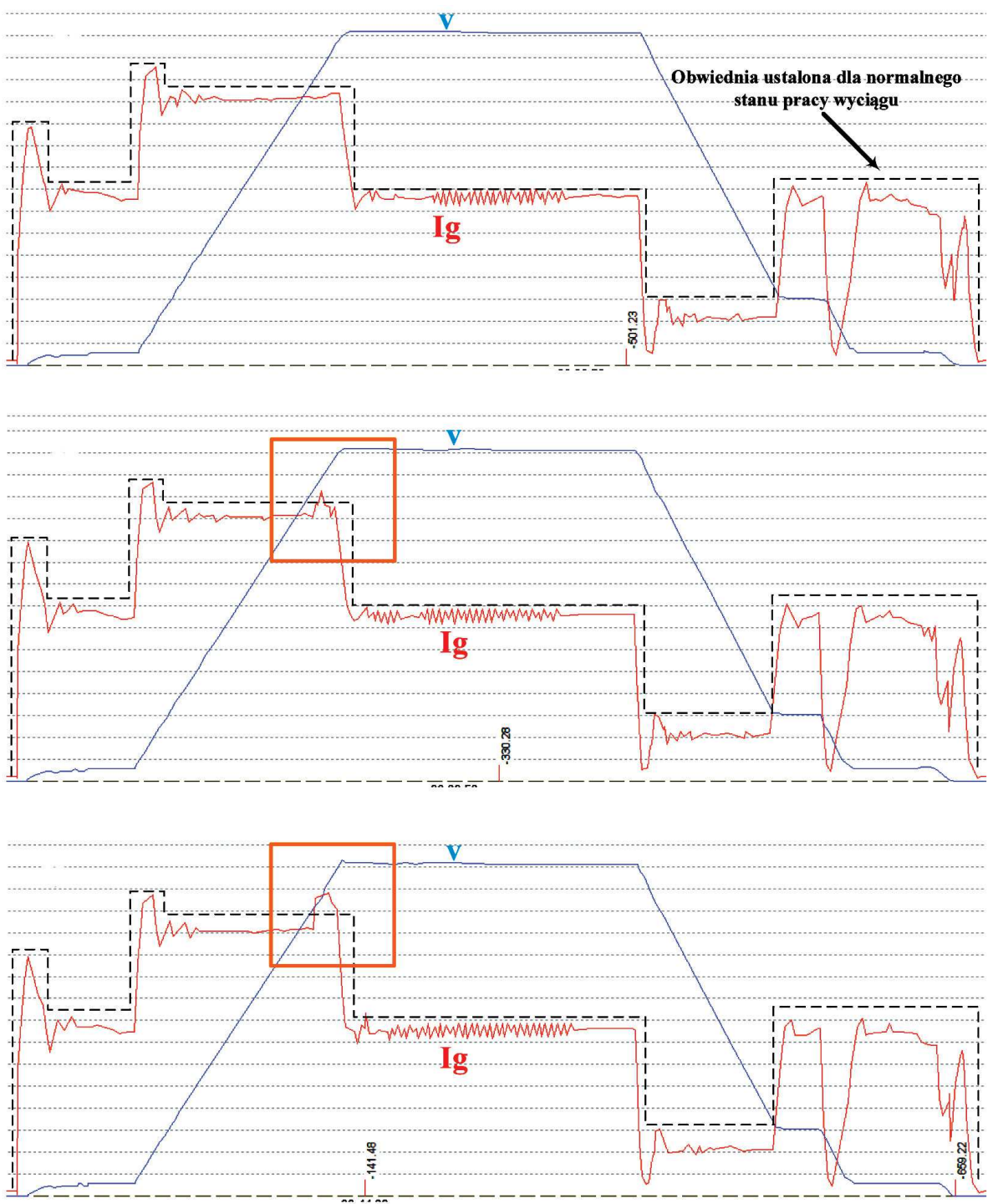

Rys. 5. Przebiegi prądu obwodu głównego Ig i prędkości naczynia v - zapisy z aparatu rejestrującego AR-3c: a) rejestracja bez widocznych zakłóceń (prawidłowe przebiegi); b) zapis na trzy cykle przed zdarzeniem; c) zapis cyklu poprzedzającego zdarzenie 
Układ regulacji zadziałał prawidłowo, wartość natężenia prądu zmniejszyła się, aby w kolejnej chwili narosnąć do wartości maksymalnej, odpowiadającej ograniczeniu wynikającemu z nastaw regulatora prądu. W tym momencie maszyna stała się maszyną jednokońcową. Po uwolnieniu naczynia 2, skip spadał w sposób niekontrolowany. Spowodowało to wzrost prędkości ponad dopuszczalną wartość i wyłączenie maszyny ze względu na przekroczenie prędkości.

\section{OPIS STANU NA PODSTAWIE REJESTRATORA}

Przeprowadzona została analiza zapisów rejestratora maszyny wyciągowej w dłuższym czasie niż tylko w chwili zdarzenia.

Analizie poddano zapisy z dziesięciu cykli przed cyklem, w którym wystąpiło zdarzenie. Na trzy cykle przed zdarzeniem nie są widoczne żadne niepokojące objawy w przebiegu prądu i prędkości (rys. 5a). $\mathrm{Na}$ każdy z przebiegów prądu na rysunku 5 nałożono obwiednię na podstawie przebiegu prawidłowego, która pozwala stwierdzić, czy w układzie nie występują anomalie. Już na trzy cykle przed wystąpieniem zdarzenia widoczny jest wzrost prądu obwodu głównego o ok. 500 A ponad wartość ustaloną dla tego fragmentu diagramu jazdy. Pełne naczynie 2 poruszało się w tym czasie w górę. Można wnioskować, że już wtedy następował kontakt naczynia z odchyloną konstrukcją zbiornika przedziału sąsiedniego. Obsługa urządzeń na podszybiu zgłaszała, że słyszalne były niepokojące odgłosy w szybie. W cyklu poprzedzającym zdarzenie wzrost prądu przy przejeździe naczynia w okolicy zbiornika przepadu osiągnął poziom 900 A i trwał znacznie dłużej (rys. 5c).

\section{WNIOSKI}

$\mathrm{Na}$ podstawie analizy zapisów rejestratora maszyny wyciągowej można stwierdzić, że możliwe było wczesne wykrycie symptomów zbliżającego się zagrożenia. Już na kilka cykli przed zdarzeniem możliwe było zaobserwowanie anomalii $\mathrm{w}$ przebiegu prądu obwodu głównego. Zmiany prądu były spowodowane zmiennym momentem obciążenia wynikającym z pojawienia się dodatkowej przeszkody dla naczynia 2 .

Nie jest możliwe wykrycie tego typu anomalii jedynie przez obserwację przebiegów prądu na pulpicie maszynisty czy w rejestratorze. Aby prawidłowo re- agować na podobne nieprawidłowości, konieczne byłoby umieszczenie dodatkowej sygnalizacji takiego stanu na pulpicie maszynisty i odpowiednie zmiany w przepisach [5].

Sygnalizacja ta, w postaci sygnału wizualnego (świecącej lampki), umieszczona na pulpicie maszynisty byłaby aktywowana przy przekroczeniu dopuszczalnej wartości natężenia prądu o założoną wartość dla danego fragmentu diagramu jazdy. Sygnalizacja założona w szybach dwuprzedziałowych o różnych poziomach wydobywczych wymagałaby od obsługi podjęcia działań sprawdzających w przypadku jej aktywacji.

Byłby to element, który powinien zwrócić uwagę obsługi, a szczególnie pracowników dozoru. Jeżeli występuje przeciążenie maszyny w postaci wzrostu wartości natężenia prądu, to jest to wynikiem działania dodatkowego momentu obciążenia napędu, który może mieć różne przyczyny. Do zadań osób kontrolujących stan techniczny zbrojenia szybowego i wyposażenia pomocniczego szybu należy ocena, czy naczynia nie napotykają przeszkód, które mogą spowodować niebezpieczne konsekwencje. Realizacja tego typu sygnalizatora jest prosta $\mathrm{z}$ technicznego punktu widzenia. Pomiar wartości natężenia prądu jest już realizowany w każdej maszynie.

\section{Literatura}

[1] Szklarski L., Zarudzki J.: Elektryczne maszyny wyciagowe, PWN, Warszawa 1998.

[2] Rozporządzenie Rady Ministrów z dnia 30 kwietnia 2004 r. $w$ sprawie dopuszczania wyrobów do stosowania $w$ zakładach górniczych, Dz.U. 2004, nr 99, poz. 1003.

[3] Kiercz M., Rokita T.: Awaria górniczego wyciagu szybowego szybu dwuprzedziałowego, „Bezpieczeństwo Pracy i Ochrona Środowiska w Górnictwie” 2018, 11: 8-13.

[4] Cyfrowy Aparat Rejestrujący AR-3c. Dokumentacja użytkownika. MicroSTER, Katowice, maj 2005.

[5] Rozporzadzenie Ministra Energii $z$ dnia 23 listopada $2016 r$ w sprawie szczegółowych wymagań dotyczacych prowadzenia ruchu podziemnych zakładów górniczych, Dz.U. 2017, poz. 1118.

dr inz. TOMASZ SIOSTRZONEK mgr inż. JAKUB WÓJCIK

Katedra Energoelektroniki i Automatyki Systemów Przetwarzania Energii Wydziat Elektrotechniki, Automatyki, Informatyki i Inżynierii Biomedycznej AGH Akademia Górniczo-Hutnicza im. St. Staszica w Krakowie al. A. Mickiewicza 30, 30-059 Kraków \{tsios, jakubwojcik\}@agh.edu.pl

mgr inż. PIOTR TRÓJCA Specjalistyczny Urzad Górniczy ul. Obroki 87, 40-833 Katowice sug@wug.gov.pl 